\title{
Experimental induction of a large phytoplankton bloom in Antarctic coastal waters
}

\author{
Susana Agustí*, Carlos M. Duarte \\ Instituto Mediterráneo de Estudios Avanzados (IMEDEA), CSIC-Universitat de les Illes Balears, \\ C/Miguel Marqués 21, 07190 Esporles, Mallorca, Islas Baleares, Spain
}

\begin{abstract}
The experimental enclosure of an Antarctic planktonic community in a large $\left(35 \mathrm{~m}^{3}\right)$ mesocosm moored in Johnson's Dock $\left(62^{\circ} 39.576^{\prime} \mathrm{S}, 60^{\circ} 22.408^{\prime} \mathrm{W}\right.$, Livingston Island, Bransfield Sector, Antarctica) was followed by a large phytoplankton bloom. This bloom, dominated by the large diatom Thalassiosira antarctica, reached a biomass 1000-fold greater than in the ambient waters. The net growth rate of $T$. antarctica averaged $0.53 \pm 0.17 \mathrm{~d}^{-1}$, with maximum net growth rates close to $1.0 \mathrm{~d}^{-1}$, exceeding the predicted maximal population growth rates by 60 to $200 \%$. The gross primary

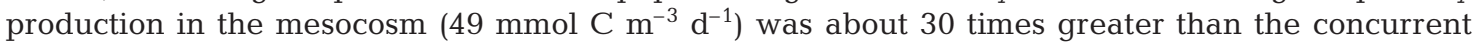
gross production in the ambient waters, while sedimentation losses removed only between 2.1 to $13 \%$ of the biomass $\mathrm{d}^{-1}$ and cell mortality was negligible. The bloom development led to a decline of dissolved inorganic nutrient concentrations to values several times lower than those in the ambient waters, indicating that the ambient nutrients were both available and sufficient to allow the development of the massive algal bloom observed. Light-limitation of the phytoplankton community was likely the factor responsible for the low biomass and production in ambient waters relative to the mesocosm, as indicated by: (1) limited water transparency of about $1 \mathrm{~m}$, which increased up to $6 \mathrm{~m}$ as a result of the sedimentation of the glacial flour in the mesocosm; (2) dense pigment packaging $\left(14.7 \pm 3 \mathrm{pg}\right.$ chl a $\left.\mathrm{\mu m}^{-3}\right)$ inside the phytoplankton cells of the community in the ambient waters compared to much lower values $\left(4.2 \pm 0.8 \mathrm{pg} \mathrm{chl} \mathrm{a} \mathrm{\mu m}^{-3}\right)$ in the mesocosm community; (3) a specific light absorption of the phytoplankton community in the ambient waters 10 times higher (average specific $\mathrm{PAR}$ absorption $\left.\pm \mathrm{SE}=0.018 \pm 0.0038 \mathrm{~m}^{-1} \mathrm{mg} \mathrm{chl} \mathrm{a}^{-1}\right)$ than in the mesocosm community $(0.0087 \pm$ $\left.0.002 \mathrm{~m}^{-2} \mathrm{mg}^{-1} \mathrm{chl} a\right) ;$ and (4) a high apparent quantum yield of the phytoplankton in the ambient waters $\left(0.091 \mathrm{~mol} \mathrm{O}_{2}[\mathrm{~mol} \text { photon absorbed }]^{-1}\right)$, 4-fold higher than that for the community developed in the mesocosm.
\end{abstract}

KEY WORDS: Southern Ocean · Phytoplankton bloom · Mesocosms $\cdot$ Light limitation · Growth rates · Light absorption · Diatoms

\section{INTRODUCTION}

Antarctic waters have the highest nutrient ( $\mathrm{N}$ and $\mathrm{P}$ ) concentrations and, therefore, potential biological production in the surface waters of the ocean, but the realised production is at least an order of magnitude below this potential (El-Sayed 1984). Hypotheses to account for this paradox span the full spectrum of possible limiting factors, including limitation by resources (nutrients and iron, light) and consumer pressure (e.g.

*E-mail: sagusti@uib.es
Holm-Hansen et al. 1984, Minas \& Minas 1992, de Baar et al. 1995). In addition to possible limiting factors, the capacity of Antarctic phytoplankton to realise the potential primary production possible with the nutrients present is believed to be constrained by the low maximum intrinsic growth rates believed to be possible in cold waters (e.g. Sommer 1989). The maximum exponential growth rates possible for the large diatoms (e.g. Thalassiosira antarctica) that often dominate Antarctic waters at in situ temperatures are believed to be on the order of about $0.3 \mathrm{~d}^{-1}$ (Banse 1982, 1991, Sommer 1989, Mura \& Agustí 1996), and seem to be 
realised in situ (Mura \& Agustí 1996). Even low loss rates would suffice to prevent biomass accumulation if Antarctic phytoplankton grow at suboptimal rates.

Research on the possible causes of the relatively low phytoplankton production and biomass in Antarctic waters has been based largely on inferences drawn from results derived from surveys or bottle experiments on board ships. Large-scale, mesocosm experiments have not been conducted in polar waters as yet, probably because of logistic difficulties involved with conducting them under the conditions prevailing in Antarctica. Such experiments would likely be instrumental in the current debate, for they could test the capacity of Antarctic phytoplankton to reach the potentially high biomass and production which the available nutrients would seem to permit.

We report here on a large phytoplankton bloom induced by the experimental enclosure of a coastal planktonic community in a large mesocosm $\left(35 \mathrm{~m}^{3}\right)$. We describe the bloom dynamics by describing the conditions (nutrients, irradiance and temperature) and the resulting production, biomass, structure and dynamics of the phytoplankton community. The mesocosm study reported was not designed to provide an experimental test of any particular hypothesis but was conducted to test the feasibility of conducting largescale experiments in Antarctic waters. The results obtained, however, are relevant to the present debate

Latitude ( $\left.{ }^{\circ} \mathrm{S}\right)$

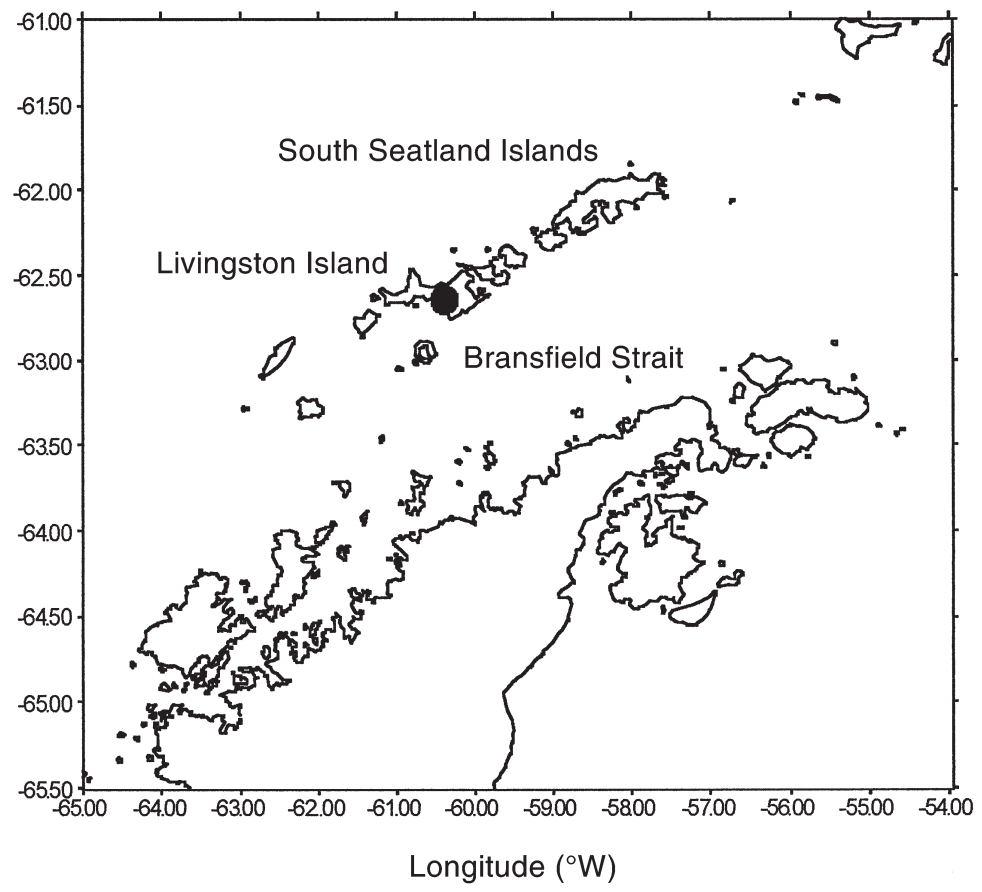

Fig. 1. Livingston Island and Johnson Dock, near the Spanish Antarctic Base 'Juan Carlos I' (•), where the experiment was conducted since they demonstrate that Antarctic phytoplankton is able to develop large blooms and remove much of the available nutrients. In doing so, this demonstration experiment paves the way for more conclusive experiments testing hypotheses on the control of planktonic production in Antarctic waters.

\section{METHODS}

The experiment was conducted in Johnson's Dock $\left(62^{\circ} 39.576^{\prime} \mathrm{S}, 60^{\circ} 22.408^{\prime} \mathrm{W}\right)$, a sheltered bay receiving glacial melt, adjacent to the Spanish Antarctic Base (Livingston Island, Shetland Islands, Bransfield Sector, Antarctica, Fig. 1), with a relatively fast water exchange rate driven by tidal exchange. A floating platform holding the mesocosm was moored in the deepest sector of the bay (about $25 \mathrm{~m}$ ) on January 18, 1999, and the mesocosm was filled with ambient, unscreened water (from a depth range of 0.5 to $3 \mathrm{~m}$ ) on January 19 . The mesocosm was a large ( $14 \mathrm{~m}$ tall, $2.3 \mathrm{~m}$ diameter) UV-stabilized polyethyelene bag with a nominal and effective volume of 50 and $31 \mathrm{~m}^{3}$, respectively. The cross-sectional area of the surface was $4.2 \mathrm{~m}^{2}$ and the bag was closed by a $2 \mathrm{~m}$ tall conical piece at the bottom, following the design of the CEPEX enclosures (Menzel \& Case 1977). The mesocosm platform was surrounded by a strong net to stop large ice blocks, preventing them from damaging the bag. Indeed, large (up to $7 \mathrm{~m}$ long, $3 \mathrm{~m}$ tall) ice blocks were often pushed by the wind and currents against the platform, leading to a displacement of the mooring by about $30 \mathrm{~m}$ from the initial position over the course of the experiment, but impinging no damage on the bag.

A goal of the feasibility study was to estimate the response time of phytoplankton blooms in the area. To ensure that a phytoplankton bloom would develop, and in anticipation of possible nutrient limitation, we were set to add nutrients to the mesocosm throughout the study. The planned nutrient additions consisted of the addition of $0.3 \mathrm{~mol} \mathrm{~N}$ (as $\mathrm{NH}_{4} \mathrm{Cl}$ ), $0.3 \mathrm{Si}\left(\right.$ as $_{6} \mathrm{Fa}_{2} \mathrm{Si}$ ), and $0.03 \mathrm{P}$ (as $\mathrm{KH}_{2} \mathrm{PO}_{4}$ ) at approximately alternate days, calculated to correspond to the highest sedimentary losses recorded in the area (Nedwell et al. 1993). A first pulse of nutrients was added on January 19, inmediately after the bag was filled. However, no additional nutrients were provided at this point, since the phytoplankton biomass had already doubled the following day (see below). Nutrient additions were 
restarted at approximately alternate days when the phytoplankton bloom collapsed some $20 \mathrm{~d}$ (February 10, 1999) later. To ensure adequate mixing, nutrient additions were made by filling a tube extending from the water surface to the bottom of the mesocosms, and withdrawing it slowly to ensure a homogeneous distribution along the water column. Iron was not added because it is relatively high in the coastal environment studied, which receives inputs of glacial materials transporting iron-rich volcanic ash derived from eruptions at near-by Depception Island. However, while analytical-grade chemicals were used for the nutrient additions, we cannot rule out the possibility that these may contain small amounts of iron, since trace metalfree techniques could not be used in such a large-scale experiment.

Samples for nutrient concentrations, phytoplankton biomass and primary production were collected from the mesocosm and the adjacent ambient waters at daily to $3 \mathrm{~d}$ intervals at about 10:00 $\mathrm{h}$ local time. We used integrated water samples (0 to $13 \mathrm{~m}$ ) to encompass the whole community, since the water column was not well mixed, as indicated by temperature and salinity profiles. The depth range used (0 to $13 \mathrm{~m}$ ) roughly encompassed the photic layer both in the mesocosm and ambient waters (see below). The water samples were transported within 30 min to the laboratory for analysis. Temperature, salinity and irradiance profiles were measured at about weekly intervals in the mesocosms, using an Anderaa T-S probe and display unit and a Licor $4 \pi$ PAR sensor, respectively. In addition, we measured, at approximately $3 \mathrm{~d}$ intervals, the transparency of the water in the mesocosms and the ambient waters with a $25 \mathrm{~cm}$ diameter Secchi disc. Sediment traps to determine phytoplankton sedimentation rates, built following Pedrós-Alió \& Mas (1993), were deployed at approximately $3 \mathrm{~d}$ intervals at $4 \mathrm{~m}$ in the mesocosms, and allowed to collect the sedimenting material for $24 \mathrm{~h}$. The material collected was used to determine chlorophyll a ( $\mathrm{chl}$ a) concentration using the procedures indicated below. We corrected the estimates of sedimentation rates obtained to calculate the sedimentation rate along the entire water column.

Samples for the determination of the concentrations of dissolved inorganic phosphate, nitrate, nitrite and silicate were kept frozen until analysed on an autoanalyzer following standard methods (Hansen \& Koroleff 1983), and ammonium concentrations were measured, within $1 \mathrm{~h}$ from collection, spectrofluorometrically following the method of Kéruel \& Aminot (1997). A variable water volume (25 to $250 \mathrm{ml}$, depending on phytoplankton biomass) was filtered through $0.45 \mu \mathrm{m}$ pore size Millipore filters for spectrofluorometric analysis of chl a concentration (Parsons et al. 1984). The filters were homogenised and kept refrigerated for ca $24 \mathrm{~h}$ in the dark while pigments were extracted in $90 \%$ acetone. Fluorescence was measured, following extraction, in a Simadzu 1501 spectrofluorometer calibrated with pure chl a (Sigma Co.)

Gross primary production was determined, at about 3 d intervals, on integrated water samples. Immediately upon collection of the samples, water was carefully siphoned into $125 \mathrm{ml}$ narrow-mouthed Winkler bottles. Five of the bottles were transported to the laboratory to measure the initial oxygen concentration, and the remaining 10 were suspended in situ, both inside and outside the mesocosms. Five of them were kept in the dark while the rest were incubated at the irradiance incident at the depth of suspension (about $1.5 \mathrm{~m})$. Gross production rates were calculated from the increased oxygen concentration after incubation of samples in the light relative to those incubated in the dark. Dissolved oxygen concentration was measured using high-precision Winkler titration after Carrit \& Carpenter (1966), using a Metrohm-682 Autotritator for the potentiometric (redox electrode) end-point detection (Oudot et al. 1988). The average coefficient of variation of the dissolved oxygen concentration was about $0.35 \%$ and the resulting detection limit for net production and respiration was about $0.0009 \mathrm{mg} \mathrm{O}_{2} \mathrm{l}^{-1}$ $\mathrm{h}^{-1}$. Oxygen evolution rates were converted into carbon incorporation assuming a photosynthetic quotient of 1.2 , and were converted to daily values using the observed photoperiod of $16 \mathrm{~h}$.

Phytoplankton cell lysis rates were estimated using the dissolved esterase method as described in Agustí et al. (1998). Dissolved esterase activity (as FDA hydrolysis) was measured in 3 replicates at each depth sampled. In short, $5 \mathrm{ml}$ of water were filtered through $0.2 \mu \mathrm{m}$ Millipore Millex filters, and $50 \mu \mathrm{l}$ of EDTA and $50 \mu \mathrm{l}$ of FDA (Sigma Co.) were added to the samples (to a final concentration of 0.02 and $0.2 \mathrm{mM}$ respectively) and mixed in a vortex mixer. After incubating the samples for an hour at $20^{\circ} \mathrm{C}$, the fluorescence emission was immediately measured in a Shimadzu RF-5000 spectrofluorometer at $451 \mathrm{~nm}$ and $510 \mathrm{~nm}$ excitation and emission (10 $\mathrm{nm}$ bandwidth) wavelengths, respectively. The particulate esterase activity (PEA), needed to estimate the lysis rate, was calculated from the measured chl a concentration, using a PEA:chl a ratio of $331 \mathrm{nmol} \mathrm{F} \mathrm{(mg}$ chl a) ${ }^{-1} \mathrm{~h}^{-1}$ derived from phytoplankton cultures (Agustí \& Duarte 2000). Phytoplankton cell lysis rates $\left(\mu_{1} \mathrm{~d}^{-1}\right)$ were calculated as the decrease in PEA with time $(t)$ due to the production of dissolved esterase activity (EA) during cell lysis. The production of dissolved EA was derived by combining the measured dissolved EA activity with estimates of the rate of loss of the activity of the enzyme calculated experimentally.

The abundance of autotrophic plankton was estimated using epifluorescence microscopy for pico- and 
nanophytoplankton. Samples were preserved in glutaraldehyde ( $1 \%$ final concentration) and filtered onto $0.6 \mu \mathrm{m}$ Nuclepore filters and the cells were counted and measured at $1000 \times$ magnification under an Olympus epifluorescence microscope. Samples for microphytoplankton counts (0.5 to $2 \mathrm{l}$, depending on density), preserved in glutaraldehyde (1\% final concentration), were pre-concentrated using a Millipore concentrator chamber (5 $\mu \mathrm{m}$ mesh size), and enumerated and counted at $200 \times$ and $320 \times$ magnification under a Leyca inverted microscope. Cell volume was calculated microscopically from measurements of the linear dimensions of at least 30 cells in each taxon. Phytoplankton biovolume was obtained as the product of cell abundance and the cell volume. Autotrophic carbon was calculated from biovolume estimates using the equations provided by Strathmann (1967).

Light absorption by suspended particles was measured, at irregular intervals, on particles collected after filtering a variable volume of water $(0.25$ to $0.5 \mathrm{l}$, depending on suspended sediment concentration) through $2.5 \mathrm{~cm}$ Whatman GF/F filters, following Mitchell \& Kiefer (1988). The measurement of optical density of particles collected on filters allows the estimation of the light absorption coefficient, because the glass fiber filter diffuses light such that scattered light is received by the photomultiplier. The pathlength amplification due to multiple scattering inside filters needs to be corrected for (Bricaud \& Stramski 1990). Seston was concentrated by filtering a variable volume of water (1 to 2.5 l, depending on suspended sediment concentration) through $2.5 \mathrm{~cm}$ Whatman GF/F filters. Light absorption by particles concentrated on the filters was measured immediately after collection. The optical density of the filters $\left(\mathrm{OD}_{\mathrm{f}}\right)$ was measured in dual beam scanning spectrophotometers (Shimadzu UV-2100 and JASCO-UV 7800) using a clean, watersaturated Whatman GF/F filter as a blank. The wet filters are placed in front of the photomultiplier and the clean, water-saturated filter used as a reference blank through baseline corrections. $\mathrm{OD}_{\mathrm{f}}$ was measured at $1 \mathrm{~nm}$ intervals between 380 and $750 \mathrm{~nm}$.

Particle light absorption $\left(a_{\mathrm{p}}, \mathrm{m}^{-1}\right)$ was calculated following the equation,

$$
a_{\mathrm{p}(\lambda)}=2.3 \mathrm{OD}_{\mathrm{f}(\lambda)} C / V \beta_{(\lambda)}
$$

where $\lambda$ is the wavelength (nm), 2.3 the factor to convert base-10 logarithms to natural logarithms, $C$ is the clearance area of the filter $\left(\mathrm{m}^{2}\right), V$ is the volume of water filtered $\left(\mathrm{m}^{3}\right)$ and $\beta$ is the wavelength-dependent pathlength amplification factor of the filters, calculated after Bricaud \& Stramski (1990). The absorption attributable to phytoplankton $\left(a_{\mathrm{ph}}\right)$ and non-algal particles $\left(a_{\mathrm{d}}\right)$ was estimated from the sestonic absorption spectra $\left(a_{\mathrm{p}[\lambda]}\right)$ by an indirect method (Bricaud \& Stramski 1990).
This method is based on the use of known ratios between light absorption by chl a at peaks and valleys of its absorption spectra $\left[a_{\mathrm{ph}}(505): a_{\mathrm{ph}}(380)=0.99\right.$ and $a_{\text {ph }}(580): a_{\text {ph }}(692.5)=0.92$ ] so as to separate the bulk particulate light spectra into a phytoplankton and a non-algal component (Bricaud \& Stramski 1990). This method is semi-empirical because it uses empirically derived relationships to approximate the absorption attributable to phytoplanktonic and non-phytoplanktonic particles from the total particulate absorption at specific wavelengths. The method of Bricaud \& Stramski (1990) calculates the light absorption coefficient by non-algal particles $\left(a_{\mathrm{d}}\right)$ as a negative exponential function of the wavelength, the parameters of which are derived as functions of the measured particulate light absorption spectra at 380,505,580, and $692.5 \mathrm{~nm}$. The light absorption coefficient for phytoplankton $\left(a_{\mathrm{ph}(\lambda)}\right)$ is then calculated by subtracting the calculated absorption spectra of non-phytoplanktonic particles from the bulk particulate absorption spectra.

Particulate light absorption was summarized by the coefficients at $675 \mathrm{~nm}$, an absorption peak of chl $a$, to examine absorption by phytoplankton (e.g. Morel \& Bricaud 1981). We also used the average light absorption between 400 and $700 \mathrm{~nm}$ (PAR) to examine the compound absorption of the different types of sestonic particles (algal and non-algal particles). The absorption at $400 \mathrm{~nm}$, where all suspended particles considered here absorb strongly, was also evaluated.

\section{RESULTS}

Surface water temperature declined from $1.6^{\circ} \mathrm{C}$ to slightly below $1.0^{\circ} \mathrm{C}$ both inside and outside the mesocosm during the study. The water column thermal structure was similar inside and outside the mesocosm throughout, and was characterised by a pycnocline at about 2 to $4 \mathrm{~m}$ depth. The temperature difference inside and outside the bags was small (mean $=0.086^{\circ} \mathrm{C}$ ), whereas the salinity structure varied much outside the mesocosm, due to changes in water masses during the experiment. The strong salinity gradient (2 salinityunits increase between the surface and $3 \mathrm{~m}$ depth) present in the ambient waters coupled with a weak thermocline $\left(0.5^{\circ} \mathrm{C}\right.$ over the same depth range) maintained a strongly stratified water column. A thermocline similar to that in the ambient waters developed inside the mesocosm during the third week of the experiment (Fig. 2), but in the absence of a similarly strong salinity gradient. The waters in the coastal area had a milky aspect, due to the glacial flour - a colloid of quartz crystals delivered by the adjacent glaciers (AzetsuScott \& Syvitski 1999) — which extended well off-shore the islands, as revealed by transects conducted aboard 

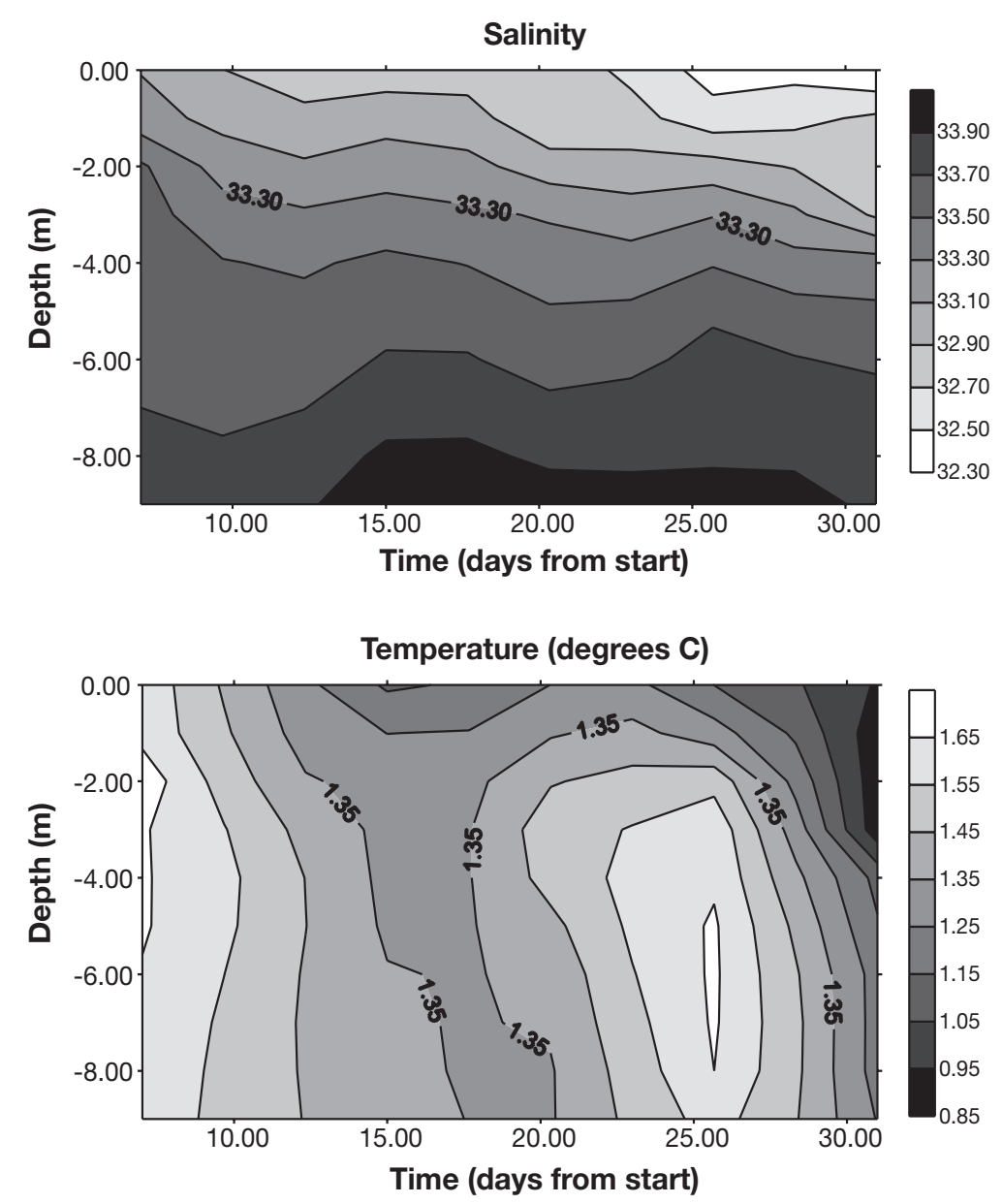

Fig. 2. Time series of temperature and salinity distribution in the water column of the mesocosm unit during the experiment (January 19, 1999, to February 21, 1999)

the Spanish RV 'Hespérides'. These observations indicate that glacial flour in the Bransfield Strait extends to the shelf of the Shetland Islands and the Antarctic Peninsula, where it probably sediments out, so that these particles do not reach the open sea. Accordingly, water transparency was poor in the ambient waters, and remained so during the study (Fig. 3). In contrast, water transparency gradually increased at a rate of $37 \mathrm{~cm} \mathrm{~d}^{-1}$ in the mesocosm, from the initial values of about $1 \mathrm{~m}$ to up to $6 \mathrm{~m}$ (Fig. 3), as a result of the sedimentation of the glacial flour. With the addition of nutrients the water transparency inside the mesocosm returned to values similar to those of the ambient waters (Fig. 3).

The underwater light environment is better described by the irradiance profiles, which showed, despite the order-of-magnitude difference in phytoplankton biomass, that the light extinction coefficient differed little between the mesocosm's interior and the ambient water (Fig. 4), except for the development of a bloom following nutrient additions at the end of the observation period (see below), when extinction coefficients in mesocosm waters were distinctively greater (Fig. 4). In contrast, the light absorption spectra showed major differences between the waters in the mesocosm and the ambient waters (Fig. 5), with the former showing spectra dominated by absorption by phytoplankton pigments, whereas the ambient waters showed absorption spectra characterised by declining absorption coefficient with increasing wavelength (Fig. 5), characteristic of inorganic particles (Kirk 1983, Duarte et al. 1998).

Dissolved inorganic nutrient concentrations were very high in the ambient waters (average of $1.1 \mu \mathrm{M}$ ammonium, $57.3 \mu \mathrm{M}$ silicate, $1.79 \mu \mathrm{M}$ phosphate, and $20.0 \mu \mathrm{M}$ nitrate + nitrite during the study), as is the case in the Southern Ocean. Changes in nutrient concentrations after nutrient additions revealed the dosage to yield a concentration increase of $5.5 \mu \mathrm{M}$ ammonia, $0.61 \mu \mathrm{M}$ phosphate, and $13.1 \mu \mathrm{M}$ silicate. The original pulse of nutrients added was not evident in the concentration of phosphate, but was clearly detected in that of ammonia, a minor (5.2\%, on average) pool of the dissolved inorganic nitrogen pool in the ambient waters, which reached concentrations 3-fold higher than average (Fig. 6). Dissolved inorganic nutrients in the mesocosm were lowered to concentrations well below those of the ambient waters $(0.5 \mu \mathrm{M}$ ammonium, $<1 \mu \mathrm{M}$ phosphate, and $3 \mu \mathrm{M}$ nitrate + nitrite), although silicate concentrations remained high (average $\pm \mathrm{SE}=54.3 \pm 2.0 \mu \mathrm{M}$ ) along the experiment. Phosphate concentrations

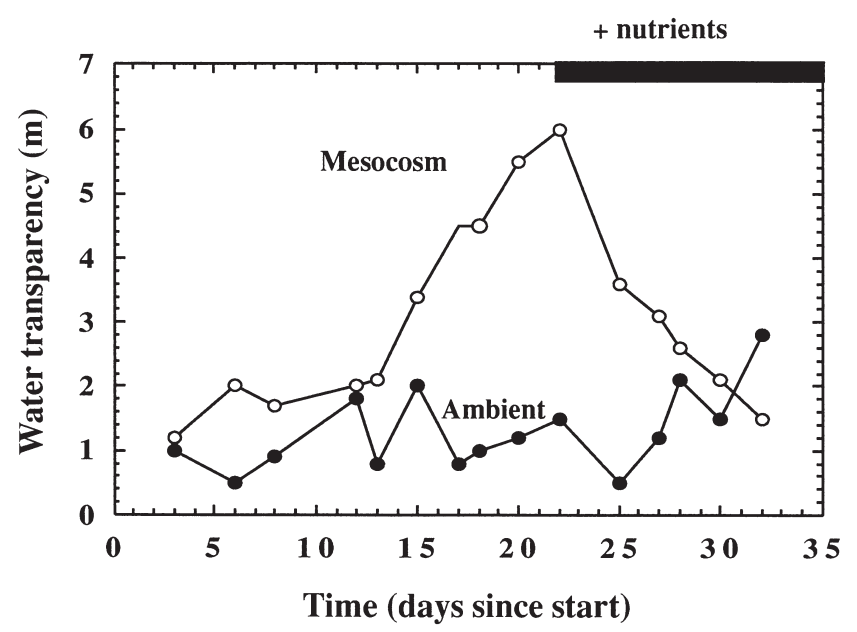

Fig. 3. Time series of water transparency, as the Secchi disk depth, in the mesocosm and the ambient waters during the experiment (January 19, 1999, to February 21, 1999) 

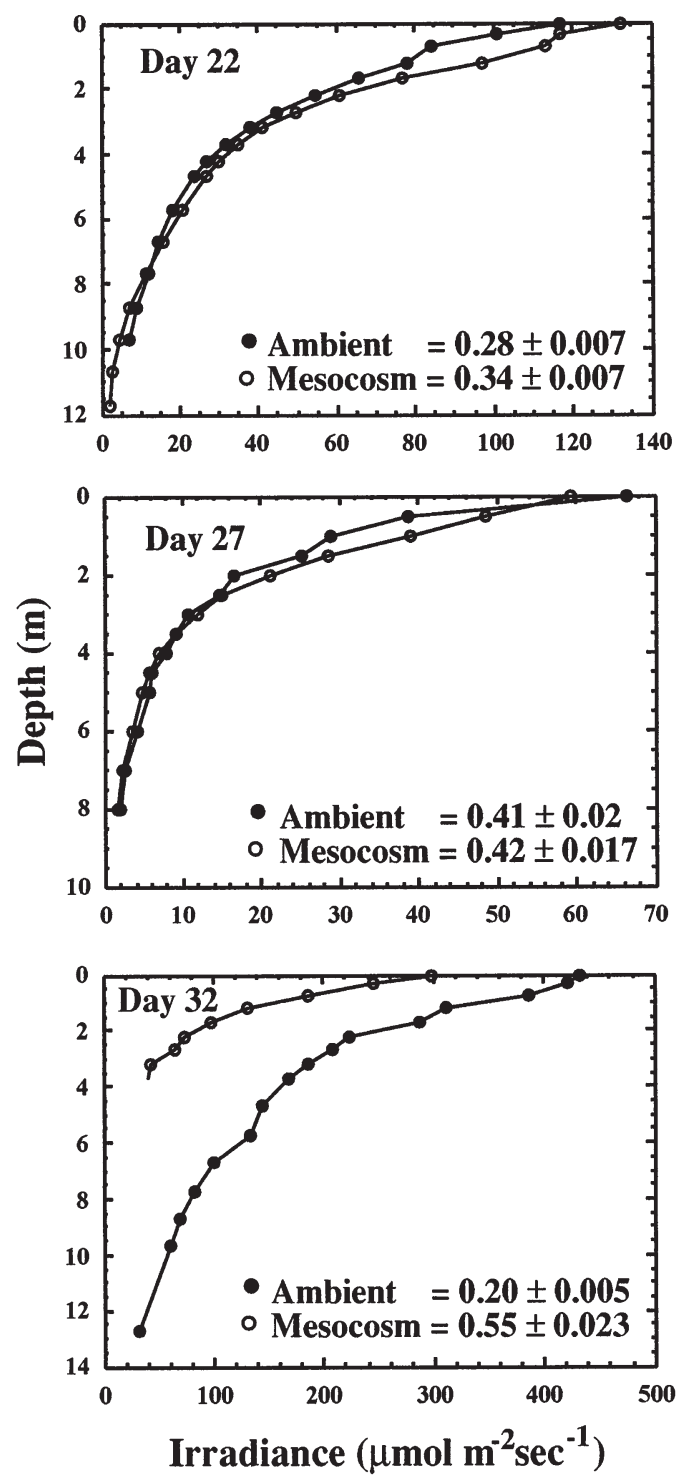

Fig. 4. Irradiance (PAR) versus depth profiles in the mesocosm and ambient waters. The values in each panel represent the estimated extinction coefficients $\pm 1 \mathrm{SE}$

recovered to levels similar to those of the ambient waters following the nutrient additions at the end of the experiment, when ammonium concentrations reached very high levels (Fig. 6).

The enclosure of the phytoplankton community in the mesocosm was followed by an immediate growth response, with a doubling of the chl a concentration already evident after $1 \mathrm{~d}$ (Fig. 7). This initial growth response continued until the integrated chl a concentration reached $36 \mu \mathrm{g} \mathrm{l}^{-1}$, about 50 times greater than the average concentrations in ambient waters, $2 \mathrm{wk}$ following the enclosure of the water in the mesocosm (Fig. 7). Subsequently, chl a concentration oscillated but declined to reach values only slightly higher than those in the ambient waters after $3 \mathrm{wk}$. Initiation of regular nutrient inputs at that time led to a new phytoplankton bloom, reaching $29 \mu \mathrm{g} \mathrm{l}^{-1}$ just before the end of the observational period (Fig. 7). The spectacular response of the phytoplankton community to the enclosure in the mesocosm accounted for the drawdown of the dissolved inorganic nutrients to levels well below those encountered in the ambient waters (Fig. 6).

The phytoplankton community in both the ambient waters and the mesocosm was dominated by microphytoplankton (mean biovolume of microphytoplankton = 58 and $96 \%$ throughout the study, respectively). The community was dominated by diatoms, where the large diatom Thalassiosira antarctica (43500 $\mu^{3}$ and $40 \mu \mathrm{m}$ average cell volume and length, respectively) was the main component (Fig. 8). It represented $87 \%$ of the microphytoplankton biovolume of the ambient waters, and $96 \%$ of that in the mesocosm during the study period. The biovolume of T. antarctica increased rapidly in the mesocosm, reaching a maximum biovolume more than 1000-fold greater than in the ambient waters 2 wk later. The large T. antarctica cells formed chains several milimeters long, easily observed by the naked eye, with a maximum concentration of 454 cells $\mathrm{ml}^{-1}$. The net logarithmic growth rate of $T$. antarctica averaged $0.53 \pm 0.17 \mathrm{~d}^{-1}$, with maximum net growth rates close to $1.0 \mathrm{~d}^{-1}$. Its biovolume subsequently declined sharply in the mesocosm to reach a minimum after $3 \mathrm{wk}$, increasing again in response to the nutrient addition (Fig. 8). Autotrophic nano- and picoplankton, composed of Chryptophyceae and eukaryotic picosized algae, were important components of the community in the ambient waters (Fig. 8). Although picoautotrophs increased rapidly in the mesocosm, they reached a biovolume only $1 \%$ of that of $T$. antarctica, and were characterised by a much smaller average net growth rate $\left(0.26 \mathrm{~d}^{-1}\right)$.

The gross primary production in ambient waters averaged $3.6 \pm 1.0 \mathrm{mmol} \mathrm{C} \mathrm{m}^{-3} \mathrm{~d}^{-1}$. In contrast, the gross primary production in the mesocosm increased greatly to reach a record high for Antarctic waters of $49 \mathrm{mmol} \mathrm{C} \mathrm{m}^{-3} \mathrm{~d}^{-1}$ (average $=35.0 \pm 7 \mathrm{mmol} \mathrm{C} \mathrm{m}^{-3} \mathrm{~d}^{-1}$ ), about 30 times greater than the concurrent gross production in the ambient waters (Fig. 9). The measured gross production rates suggest, when scaled to the autotrophic biomass in the mesocosm, gross exponential growth rates averaging $1.44 \pm 0.31 \mathrm{~d}^{-1}$, about 3 times greater than the average net exponential growth rate calculated from the time course of biomass development. Clearly, loss factors were important in the mesocosms. Sedimentation losses removed between 2.1 and $13 \%$ of the biomass $\mathrm{d}^{-1}$, and are, therefore, negligible compared to the loss rate of $1 \mathrm{~d}^{-1}$ resulting 


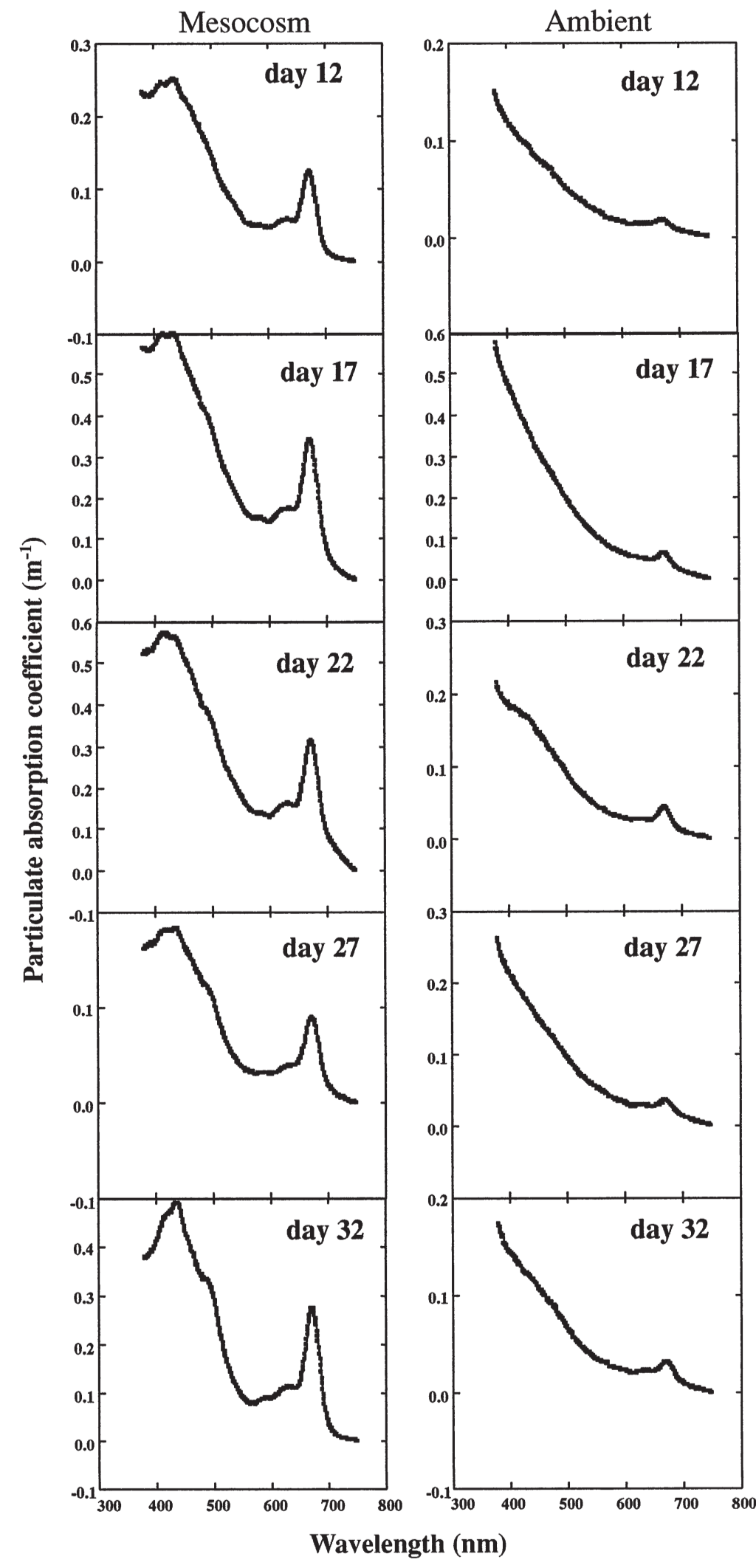

Fig. 5. Particulate light (PAR) absorption spectra in the mesocosm and the ambient waters during the experiment (January 19, 1999, to February 21, 1999) from the comparison of the average gross and net growth rates. Cell mortality too was a negligible source of losses in the mesocosm, because estimated cell lysis rates were low (Fig. 10), averaging $0.0012 \pm 0.0003 \mathrm{~d}^{-1}$ during the study, or about $0.1 \%$ of the gross growth rate. Specific lysis rates were substantially (about 60-fold) greater in the ambient waters, averaging 0.0068 $\pm 0.001 \mathrm{~d}^{-1}$, but too small to be an important loss factor there. Hence, the bulk of the losses must have derived from physiological processes, such as photorespiration, excretion, and grazing. The importance of grazing is supported by (1) the development of exceedingly dense populations of tintinnids, which consumed Thalassiosira cells, and (2) the exponential development of a dense population of planktonic amphipods (Duarte \& Agustí unpubl.).

The initial increase in mesocosm water transparency is surprising, as a large phytoplankton community developed concurrently, which should have made an important contribution to light absorption. The unexpected result was the outcome of the high light attenuation attributable to the glacial flour, such that the extra photons that became available by the settling of the glacial flour were now absorbed by the phytoplankton, resulting in the remarkably similar irradiance-depth profiles observed during most of the experiment (Fig. 4). Indeed, the mesocosm phytoplankton community made less efficient use of light than the ambient community. The latter achieved higher primary production rates, both bulk rates and per unit chlorophyll, at lower irradiance than the mesocosm community (Fig. 11). The production of the community in the ambient community compensated the respiratory demands at $3 \%$ of the incident irradiance, whereas the community that developed in the mesocosm required $12 \%$ of the incident irradiance to compensate respiratory losses (Fig. 10). Although the primary production reached by the mesocosm community was up to 3 times that in the ambient waters at high irradiance, the production achieved per unit biomass was much greater in the ambient community (Fig. 11). Consequently, the assemblage in the ambient waters was shade-adapted, allowing its growth at the low underwater irradiance characteristic of ambient waters.

The adaptation of the ambient communities to the low underwater irradiances of the Antarctic coastal waters examined was reflected in the high internal packaging of chl $a$, which averaged $14.7 \pm 3 \mathrm{pg} \mathrm{chl} \mathrm{a} \mathrm{mm}^{-3}$, compared to the 
much smaller values (average $\pm \mathrm{SE}=4.2 \pm 0.8 \mathrm{pg}$ chl a $\mu^{-3}$ ) of the mesocosm community (Fig. 12). The internal chl a packaging declined during the first 2 wk of the bloom development in the mesocosm (Fig. 12), suggesting a decreasing importance of light capture by the individual cells as a factor regulating growth.

In the ambient waters, light absorption was dominated by non-phytoplankton material, which absorbed about 3 times more light (PAR), on average, than the phytoplankton (Fig. 12). Conversely, the phytoplankton absorption coefficient for PAR was an order of magnitude greater in the mesocosm than that in ambient waters, and far exceeded light absorption by nonphytoplanktonic particles, which was only half of that in the ambient waters (Fig. 12). Light absorption mea-

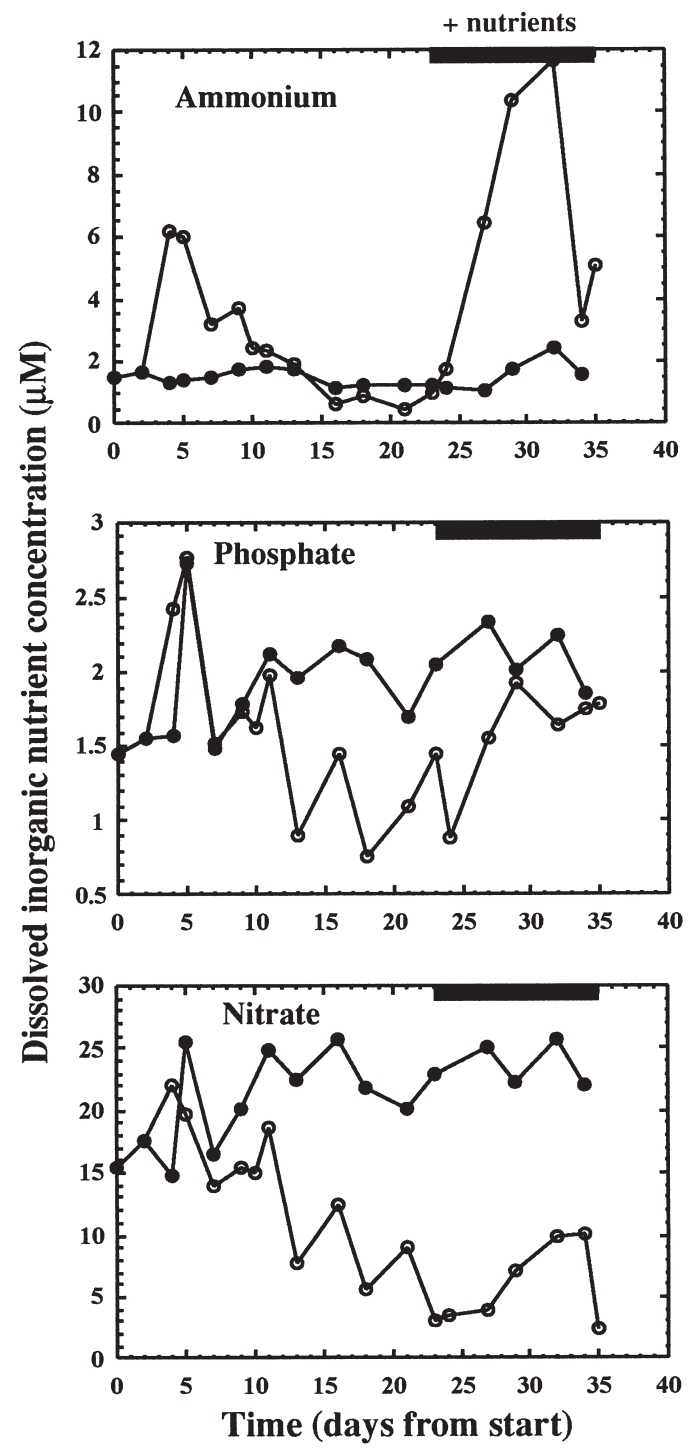

Fig. 6. Depth-integrated concentration of dissolved inorganic nutrients in the mesocosm $(O)$ and ambient waters $(\bullet)$ during the experiment (January 19, 1999, to February 21, 1999)

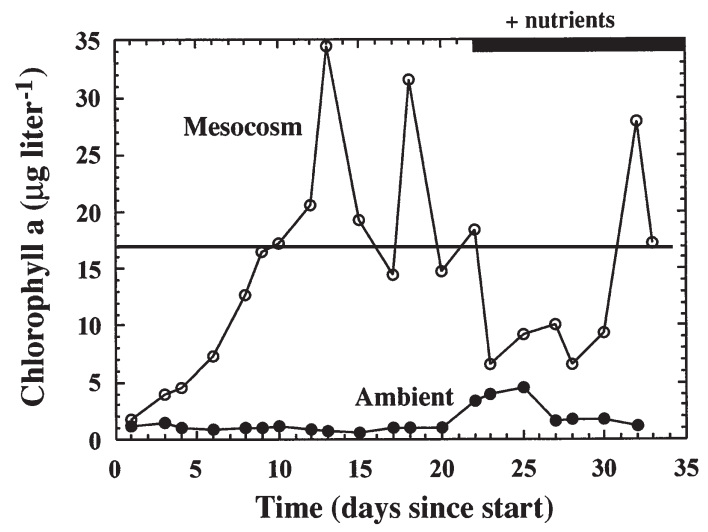

Fig. 7. Depth-integrated concentration of chl a in the mesocosm and ambient waters during the experiment (January 19, 1999, to February 21, 1999)

surements underestimate the effect of glacial flour on the underwater light climate, for these particles attenuate light largely by increasing scattering (Kirk 1983), rather than directly absorb it. Even so, the efficiency of light absorption by phytoplankton was much greater in the ambient waters (average specific PAR absorption \pm

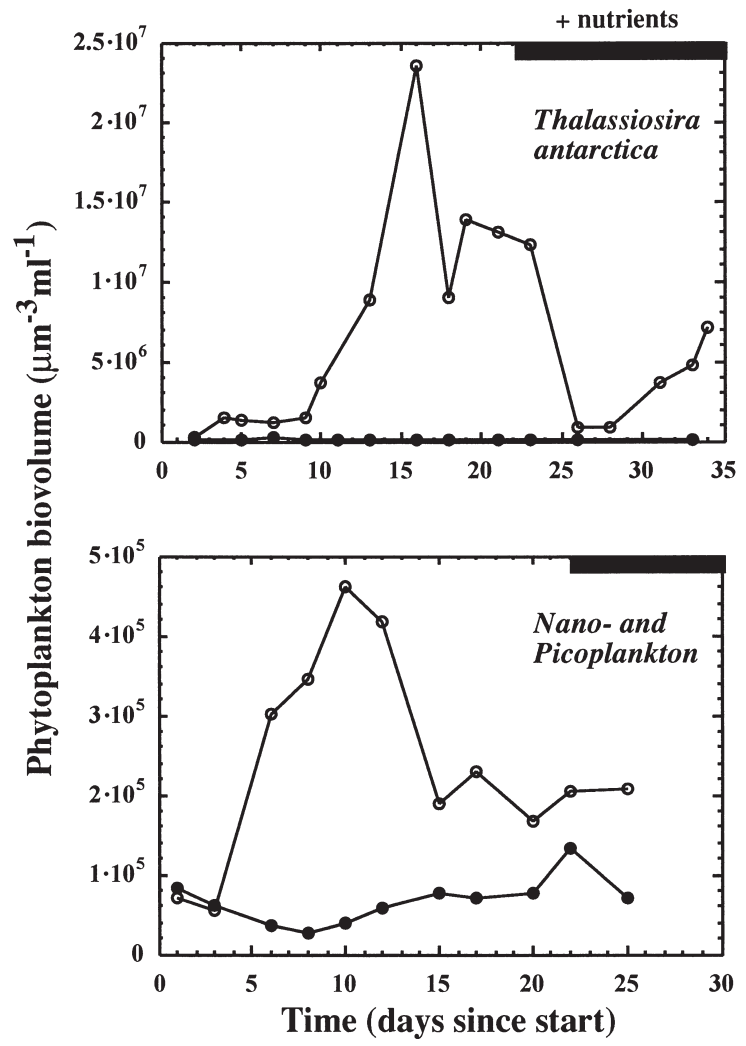

Fig. 8. Depth-integrated biovolume of diatoms and nano- and picophytoplankton in the mesocosm (O) and the ambient waters (๑) during the experiment (January 19, 1999, to February 21, 1999) 


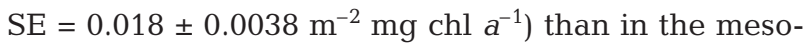
cosm community (average specific PAR absorption \pm $\left.\mathrm{SE}=0.0087 \pm 0.002 \mathrm{~m}^{-2} \mathrm{mg} \mathrm{chl} a^{-1}\right)$.

\section{DISCUSSION}

The results described portray the development of a spectacular phytoplankton bloom following confinement in a large mesocosm. The bloom developed in a single mesocosm experiment designed as part of a feasibility study, so that the elucidation of the causes for the development of such large bloom could not be the goal of the study. However, the experiment conducted represents a first demonstration of the feasibility of large-scale experiments in polar waters, and consideration of inferences possible from the results presented is important as (1) a test bench for some paradigms on the regulation of Antarctic phytoplankton growth, and (2) to design future experiments, once their feasibility has been demonstrated here. The main insights derived from this feasibility study are the demonstration of the capacity of Antarctic phytoplankton communities to develop large blooms at the conditions provided by the mesocosm and, secondly the surprisingly fast development of the bloom, which reached a phytoplankton biomass 50 -fold above those in the ambient waters within $2 \mathrm{wk}$.

The unexpectedly rapid bloom development was the result of very fast net growth rates, averaging $0.53 \pm$ $0.17 \mathrm{~d}^{-1}$, with maximal net growth rates up to $1.0 \mathrm{~d}^{-1}$, and calculated gross growth rates in excess of $1.4 \mathrm{~d}^{-1}$. Moreover, these fast growth rates were not achieved through the development of small autotrophs, but through the development of a record-dense population of the large diatom Thalassiosira antarctica. The rapid growth rates greatly exceed present estimates for the maximum growth rates for a large diatom at the temperature encountered in the experiment. The extrapolation of the relationship between phytoplankton cell size and growth rate (Banse 1982) yields predicted maximal growth rates of about $0.33 \mathrm{~d}^{-1}$ at the summer temperatures in Antarctic waters (cf. Sommer 1989), and the gross growth rates of large Antarctic diatoms have been reported to be $<0.6 \mathrm{~d}^{-1}$ (Sommer 1989, Mura \& Agustí 1996). The maximal net growth rates observed here exceed the predicted maximal population growth rates by 3 -fold, and the calculated gross growth rates of the mesocosm community are 4 -fold greater than these maximal values. Eppley (1972) fitted a temperature-dependent upper boundary to the growth rate of marine phytoplankton and predicted a maximal growth rate of about $0.9 \mathrm{~d}^{-1}$ at the temperature encountered in this study. The gross growth rates calculated for the $T$. antarctica population exceeds this

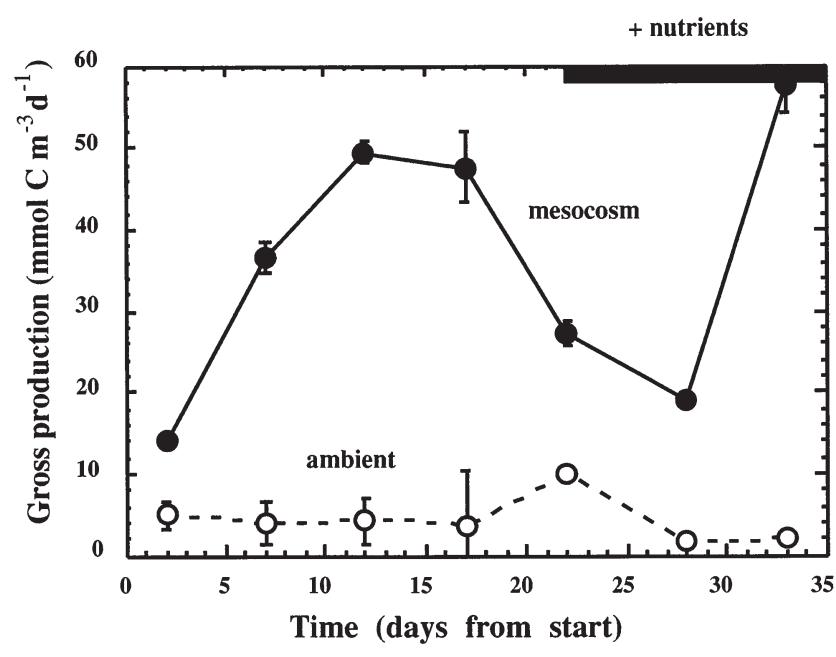

Fig. 9. Gross primary production of phytoplankton in the mesocosm and ambient waters during the experiment (January 19, 1999, to February 21, 1999)

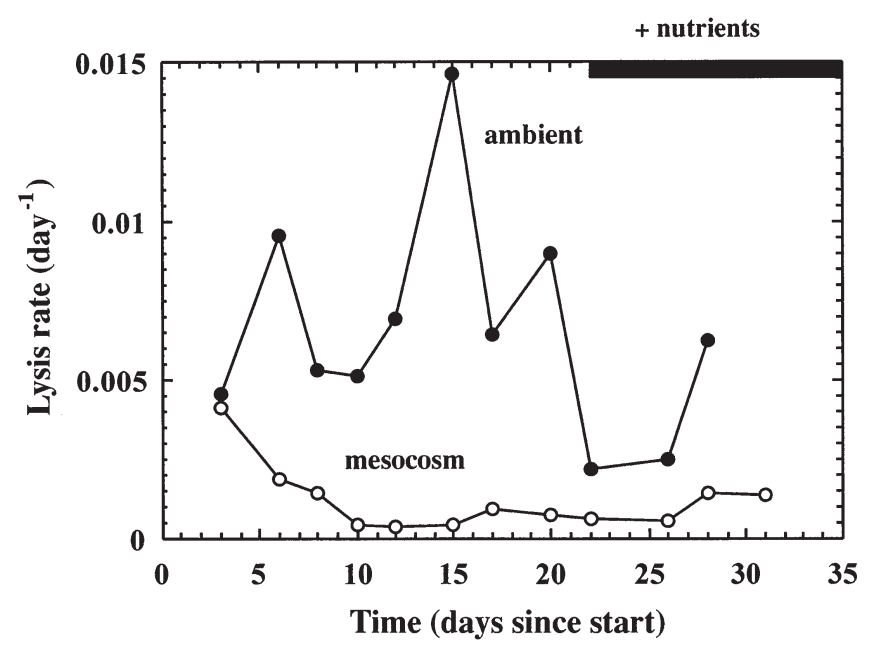

Fig. 10. Phytoplankton cell lysis rates in the mesocosm and ambient waters during the experiment (January 19, 1999, to

February 21, 1999)

maximum even though the species is much larger than the average for marine phytoplankton. The results presented call for a revision of present estimates of the temperature- and size-dependence of maximal phytoplankton growth rates.

That the growth rate of the phytoplankton community exceeded the theoretical maximal growth rates clearly indicates that the growth conditions encountered in the mesocosm were near-optimal. Hence, the low water temperature cannot possibly be invoked to account for the failure of Antarctic phytoplankton to use up the available nutrients. The development of the phytoplankton bloom could potentially be ascribed to 
the nutrient pulse provided at the start of the experiment. However, although we are unable to falsify this or other possibilities, due to lack of replication of the mesocosm, the data obtained suggest nutrient limitation of the ambient community to be an unlikely explanation for the observed bloom development. The reason for this contention is that nutrient concentrations were very high in the ambient waters, characteristic of the values encountered in Antarctic surface waters, so that the single initial pulse was negligible relative to the ambient phosphate and dissolved inorganic nitrogen already present in the waters. Indeed, full use of the initial nutrient addition would have only supported $<15 \%$ of the biomass developed in the mesocosm. Furthermore, the development of the mesocosm bloom depleted the nutrient pool to values well below those in the ambient waters, particularly for nitrate, which was reduced to concentrations 7 -fold lower than those in the ambient waters. Clearly, the ambient nutrient levels present in the mesocosm at the start of the experiment were not only available but were also sufficient to allow the development of the massive algal
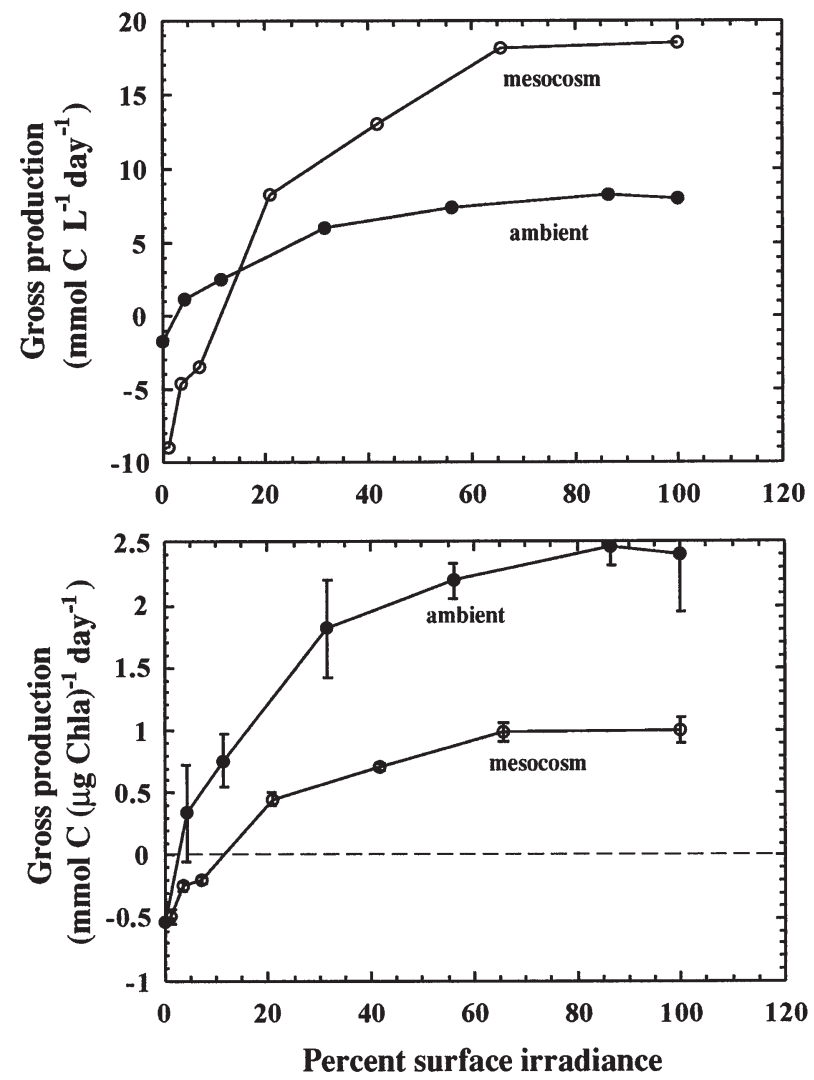

Fig. 11. Photosynthesis (both as bulk and chl a-specific rates) response to irradiance (as percent of the surface irradiance) of the phytoplankton communities developing in the mesocosm and ambient waters, 3 wk after initiation of the study. Surface irradiance was $137 \mu \mathrm{mol}$ photons $\mathrm{m}^{-2} \mathrm{~s}^{-1}$
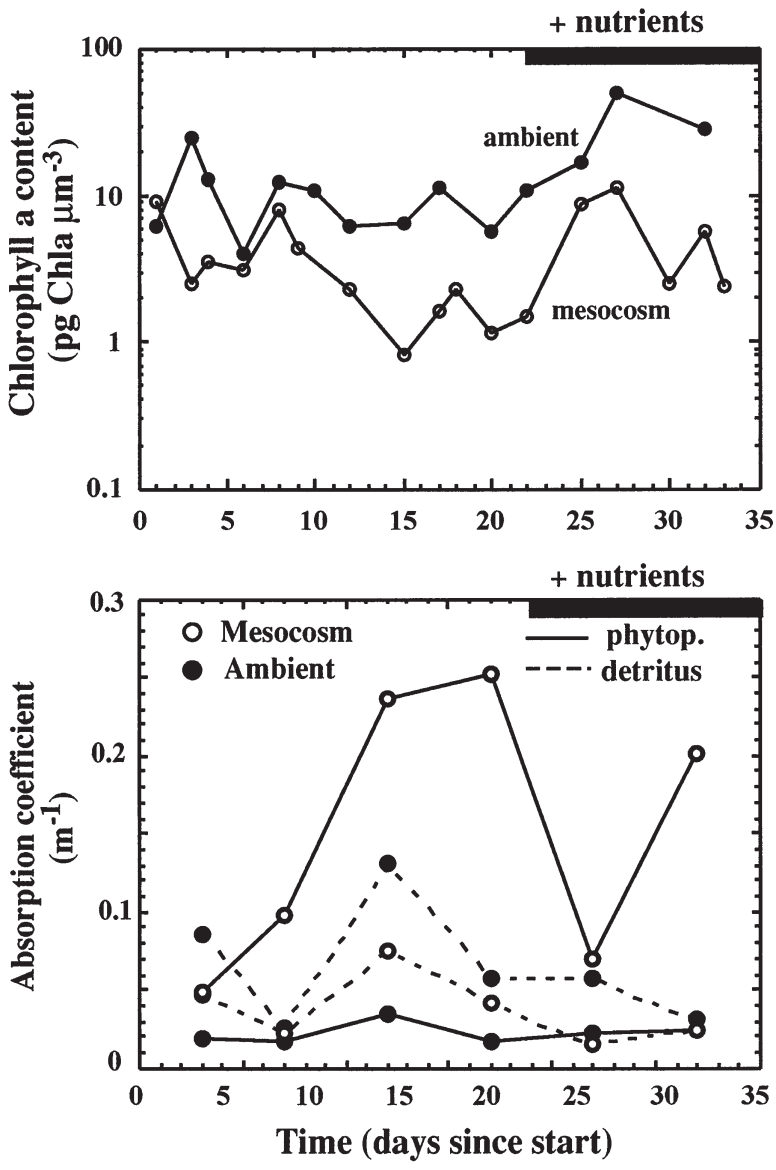

Fig. 12. Chl a packaging inside phytoplankton cells and the absorption coefficient of phytoplankton and non-phytoplanktonic particles in the mesocosm and ambient waters during the experiment (January 19, 1999, to February 21, 1999)

bloom observed. Although the nutrient pools were not raised substantially above the ambient levels, nitrogen was provided as ammonia, whereas nitrate is - by farthe dominant form in the ambient waters, which may have had a positive effect on algal growth. Moreover, iron supply, which has been claimed to limit phytoplankton production in Antarctic waters (de Baar et al. 1995), is relatively high in the coastal environment studied, which receives inputs of glacial materials transporting iron-rich volcanic ash derived from eruptions at near-by Depception Island.

We propose that the evidence presented here points to light-limitation of the phytoplankton community in ambient waters as the factor responsible for its low biomass and production relative to the mesocosm. Incident irradiances are generally low in the area, due to the dominance of cloud cover. The glacial flour, consisting of quartz and feldspar particles released from melting icebergs (cf. Azetsu-Scott \& Syvitski 1999), greatly increased light extinction, creating a shaded underwater environment imparing phytoplankton growth. Light 
limitation is further indicated by the dense pigment packaging inside the phytoplankton cells, leading to high light harvesting efficiency of the phytoplankton community in the ambient waters. The specific light absorption at $675 \mathrm{~nm}$, a distinct peak absorption by chl a, of the phytoplankton community in the ambient water averaged $8.4 \mathrm{\mu m}^{2} \mathrm{cell}^{-1}$, twice as high as that predicted $\left(4.5 \mathrm{\mu m}^{2} \mathrm{cell}^{-1}\right)$ from the internal chl a concentration of the community (Agustí 1991), indicative of a very high absorption efficiency in the ambient community. In contrast, the specific absorption at $675 \mathrm{~nm}$ by the Thalassiosira antarctica population developed in the mesocosm $\left(805 \mu^{2}\right.$ cell $\left.^{-1}\right)$ was within $3 \%$ of that predicted $\left(779 \mu^{2}\right.$ cell $\left.^{-1}\right)$ from the estimated internal chl a concentration by extrapolating from a general equation (Eq. 11 in Agustí 1991). The very high light use efficiency of the ambient population also resulted in a very high specific absorption coefficient (at $675 \mathrm{~nm}$ ) per unit biovolume $\left(0.32 \mu^{-1}\right)$ compared to values predicted

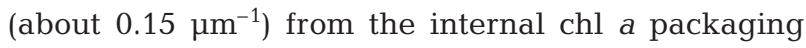
(Agustí 1991), compared to a close agreement between predicted and observed values (both at about 0.025 $\mu^{-1}$ ) in the mesocosm population. Hence, the community in the ambient waters had an outstanding capacity for light harvesting even after considering the size and chl a packaging of the cells by use of the allometric equations developed by Agustí (1991).

As a consequence of the high light-harvesting efficiency of the ambient population, its P-I curve was characteristic of shade-adapted phytoplankton. This resulted in rather contrasting quantum yields for photosynthesis for the ambient and mesocosm community. These were calculated from the initial slope of the photosynthetic rate versus the light absorbed, where the light absorbed during the $24 \mathrm{~h}$ experiment was derived as the product of the percent surface irradiance received at the incubation depth, the total irradiance received just below the surface during the experimental period and the light absorption efficiency of the algae. The calculated apparent quantum yield for the ambient community was high, at $0.091 \mathrm{~mol} \mathrm{O}_{2}$ (mol photon absorbed $)^{-1}$, characteristic of values estimated in cultures using gross oxygen release (e.g. Sakshaug 1993), whereas the apparent quantum yield was much lower for the mesocosm community $\left(0.023 \mathrm{~mol} \mathrm{O}_{2}[\mathrm{~mol}\right.$ photon absorbed $]^{-1}$ ). The high quantum yield obtained for the ambient community was indicative of their adaptation to the shaded environment they inhabited, while the 4-fold lower light use efficiency of the mesocosm community indicated a relaxed dependence on light as a critical resource. These observations portray an ambient phytoplankton community that experienced shade-stress.

The transparency increase within the mesocosm, which accompanied the bloom development, was asso- ciated with (1) a 4 -fold reduction of the pigment packaging, (2) a reduction of the specific chl a absorption coefficient to half these values, and (3) a less efficient use of low light levels, suggesting a substantial reduction of the role of light as a limiting resource. A similar light extinction coefficient in the mesocosm and ambient waters following bloom development, despite the major differences in the phytoplankton community, further proved the importance of light limitation. The similar coefficient shows that every photon absorbed by inorganic materials in the ambient waters was absorbed by phytoplankton pigments in the mesocosm. That the dense mesocosm community was not able to deplete the ambient irradiance below the level in the ambient community suggests that this extinction coefficient provides the minimum photon flux needed to maintain the growth of the individual cells. Vertical mixing may have been reduced, thereby affecting phytoplankton growth. The improvement of the light regime inside the mesocosm resulted from the reduced mixing in the enclosed waters. While the strong pycnocline present in both the ambient and mesocosm waters prevents vertical mixing from reaching any substantial depth, this mixing maintains the glacial flour in suspension in the ambient waters, whereas the much reduced turbulence inside the bags was responsible for its sedimentation, which was the main factor improving the light available for phytoplankton growth.

Indeed, the development of an important bloom of a large diatom such as Thalassiosira antarctica, despite reduced mixing inside the mesocosm, is in contrast to the common notion that large diatoms depend on strong mixing to dominate marine communities (Margalef 1978). The observation of fairly low sedimentation rates ( 2.1 to $13 \%$ of the biomass present $\mathrm{d}^{-1}$ ) in the mesocosm further indicates that sinking losses were not important for this large diatom. T. antarctica must, therefore, be able to exert some form of active buoyancy control to maintain their populations in the absence of vigorous mixing. On the other hand, the observation that reduced mixing, due to its improvement of the light climate, led to the development of the large bloom observed is consistent with hypotheses and models of the role of reduced vertical mixing on bloom formation in the sea (cf. Mann \& Lazier 1991)

On the basis of the various pieces of evidence discussed, we contend light limitation to be the principal factor precluding the phytoplankton from reaching the potential production possible in these nutrient-rich waters, in agreement with previous studies in the Brasnfield area (Mitchell \& Holm-Hansen 1991, Mitchell et al. 1991). Whereas in coastal water suspended glacial flour may be the main contributor to a shaded underwater environment, the vigorous mixing charac- 
teristic of the open Southern Ocean, with mixing depths up to 200 m (Mitchell \& Holm-Hansen 1991, Mitchell et al. 1991, Mura et al. 1995, Mura \& Agustí 1996) may also result in a shaded environment for phytoplankton growth there. The capacity to use the large pool of available nutrients has been, therefore, proposed to depend on an improvement of the light environment associated with increased stratification strength (Mitchell \& Holm-Hansen 1991, Mitchell et al. 1991). Any parallels between the response of the nearshore community investigated here and that of open-ocean communities remain, however, speculative.

The dominance of diatoms in Antarctic, and in general Polar, waters has been attributed to their unique capacity to survive the long periods of darkness characteristic of these seas (Peters \& Thomas 1996). Indeed, this trait is believed to be sufficiently important to have allowed diatoms to survive the prolonged darkness period of mass extinctions known as the Cretaceous Tertiary Boundary Darkness with only a minor rate of taxon extinction compared to other planktonic groups (Griffis \& Chapman 1988). Diatoms are both able to survive long periods of prolonged darkness and to show a very rapid response to the occasional periods of improved underwater light conditions (Peters \& Thomas 1996), such as realised in the mesocosm. Indeed, once conditions become favourable for growth, such as in the mesocosm, diatom growth increases rapidly allowing them to benefit from the occasional windows of favourable conditions encountered in the otherwise hostile polar waters.

The reason for the decline of the bloom to values close to those in ambient waters, some $3 \mathrm{wk}$ after the initiation of the experiment are unresolved, but some highly plausible hypotheses can be advanced. The comparison of the gross and the net growth rates indicates a high loss rate of about $1 \mathrm{~d}^{-1}$. Phytoplankton cell lysis and sedimentation losses, which were quantified, account for only $10 \%$ of the losses, so that the bulk must be due to grazing. Indeed, bloom development was followed by the development of a large population of tintinnids, reaching 13000 individuals $\mathrm{l}^{-1}$, which were observed to graze on the diatoms (Duarte \& Agustí unpubl. obs.). In addition, a large population of planktonic amphipods developed in the mesocosm, reaching peak densities of up to 1000 adults $\mathrm{m}^{-3}$ (Duarte \& Agustí unpubl obs.). The grazing pressure from the exceedingly large heterotroph populations developed in the mesocosm was almost certainly responsible for the bulk of the losses. Moreover, the losses imposed by these heterotrophs must have increased progressively as their populations developed. A simultaneous increase in grazing pressure, and a depletion of nutrients in the ambient waters would have brought an end to such a bloom. Nutrient addi- tions following bloom collapse induced a new bloom, but only after $10 \mathrm{~d}$, whereas a faster response was expected if nutrient limitation was the sole cause of the decline of the bloom.

The mesocosm experiment provides some insight into the probable factors preventing the high potential fertility of Antarctic coastal waters from being realised. These factors need be tested through additional experimental studies involving proper replication and controls of large experimental units. This is particularly important since the design of the experiment precludes robust identification of the role of light versus nutrient limitation as the factors limiting algal growth in the environment studied. Properly controlled mesocosm experiments must be conducted to provide conclusive demonstration of the factors controlling phytoplankton growth in Antarctic coastal waters. Even so, the findings from the feasibility study reported here indicate that maximum net growth rates of large Antarctic phytoplankton are much greater (at least 3-fold) than previously believed, and demonstrate that a dominance of large diatoms is possible under limited mixing. These conclusions, derived from a limited demonstration experiment, reveal the increasing importance and possibilities of conducting large-scale experiments in high-latitude waters, and their role in greatly enhancing the presently limited understanding of the regulation of autotrophic plankton production.

Acknowledgements. This research was part of the ESEPAC programme funded by the Spanish National Antarctic Programme (CICYT ANT97-0273). We thank Esther Benavent for assistance in the laboratory and the field, V. Alvá for assistance in the field, the personnel of the UGBO and crew of the RV 'Hespérides' for assistance in deploying the mesocosm platform, the personnel of the Spanish Antarctic Base 'Juan Carlos I' for support during the study, and J. Kalff for useful comments.

\section{LITERATURE CITED}

Agustí S (1991) Allometric scaling of light absorption and scattering by phytoplankton cells. Can J Fish Aquat Sci 48:763-767

Agustí S, Duarte CM (2000) Strong seasonality in phytoplankton cell lysis in the NW Mediterranean littoral. Limnol Oceanogr 45:940-947

Agustí S, Satta MP, Mura MP, Benavent E (1998) Dissolved esterase activity as a tracer of phytoplankton lysis: evidence of high phytoplankton lysis rates in the northwestern Mediterranean. Limnol Oceanogr 43:1836-1849

Azetsu-Scott K, Syvitski JPM (1999) Influence of melting icebergs on distribution, characteristics and transport of marine particles in an East Greenland fjord. J Geophys Res 104(C3):5321-5328

Banse K (1982) Cell volumes, maximal growth rates of unicellular algae and ciliates, and the role of ciliates in the marine pelagic. Limnol Oceanogr 27:1059-1071

Banse K (1991) Rates of phytoplankton cell division in the 
field and in iron enrichment experiments. Limnol Oceanogr 36:1886-1898

Bricaud A, Stramski D (1990) Spectral absorption coefficients of living phytoplankton and non-algal biogenous matter: a comparison between the Peru upwelling area and the Sargasso Sea. Limnol Oceanogr 35:562-582

Carrit DE, Carpenter JH (1966) Comparison and evaluation of currently employed modifications of the Winkler methods for determinating dissolved oxygen in sea water. A NASCO report. J Mar Res 24:286-318

de Baar HJW, de Jong JTM, Bakker DCE, Loscher BM, Veth C, Bathmann U, Smetacek VS (1995) Importance of iron for plankton blooms and carbon dioxide drawndown in the Southern Ocean. Nature 373:412-415

Duarte CM, Agustí S, Satta MP, Vaqué D (1998) Partitioning particulate light absorption: a budget for a Mediterranean bay. Limnol Oceanogr 43:236-244

El-Sayed SZ (1984) Productivity of the Antarctic waters: a reappraisal. In: Holm-Hansen BL, Gilles R (eds) Marine phytoplankton and productivity. Springer Verlag, Berlin, p 19-34

Eppley RW (1972) Temperature and phytoplankton growth in the sea. Fish Bull 70:1063-1085

Griffis K, Chapman DJ (1988) Survival of phytoplankton under prolonged darkness: implications for the Cretaceous Tertiary Boundary darkness hypothesis. Palaeogeogr Palaeoclimatol Palaeoecol 67:305-314

Hansen HP, Koroleff F (1983) Determination of nutrients. In: Grasshoff K, Ehrharat M, Kremling K (eds) Methods of seawater analysis, 2nd edn. Verlag Chemie, Weinheim, p 159-228

Holm-Hansen O, El-Sayed SZ, Franceschini GA, Cuhel RL (1984) Primary production and the factors controlling phytoplankton growth in the southern ocean. In: HolmHansen BL, Gilles R (eds) Marine phytoplankton and productivity. Springer Verlag, Berlin, p 11-50

Kéruel R, Aminot A (1997) Fluorometric determination of ammonia in sea and estuarine waters by direct segmented flow analysis. Mar Chem 57:265-275

Kirk JTO (1983) Light and photosynthesis in aquatic ecosystems. Cambridge University Press, Cambridge

Mann KH, Lazie JRN (1991) Dynamics of marine ecosystems. Biological-physical interactions in the oceans. Blackwell, London

Margalef R (1978) Life forms of phytoplankton as survival alternatives in an unstable environment. Oceanol Acta 1: 493-510

Menzel DW, Case J (1977) Concept and design: controlled ecosystem pollution experiment. Bull Mar Sci 27:1-7

Minas HJ, Minas M (1992) Net community production in 'High Nutrient-Low Chlorophyll' waters of the tropical

Editorial responsibility: Otto Kinne (Editor),

Oldendorf/Luhe, Germany and Antarctic Oceans: grazing vs iron hypothesis. Oceanol Acta 15:145-162

Mitchell BG, Holm-Hansen O (1991) Observations and modeling of the Antarctic phytoplankton crop in relation to mixing depth. Deep-Sea Res 38:981-1007

Mitchell BG, Kiefer DA (1988) Chlorophyll a specific absorption and fluorescence excitation spectra for phytoplankton. Deep-Sea Res 35:639-663

Mitchell BG, Brody EA, Holm-Hansen O, McCain C, Bishop J (1991) Light limitation of phytoplankton biomass and macronutrient utilization in the Southern Ocean. Limnol Oceanogr 36:1662-1677

Morel A, Bricaud A (1981) Theoretical results concerning light absorption in a discrete medium, and application to specific absorption of phytoplankton. Deep-Sea Res 28: $1375-1393$

Mura MP, Agustí S (1996) Growth rates of coastal Antarctic diatoms estimated by in situ dialysis incubations. Mar Ecol Prog Ser 144:237-245

Mura MP, Satta MP, Agustí S (1995) Water-mass influences on summer Antarctic phytoplankton biomass and community structure. Polar Biol 15:15-20

Nedwell DB, Walker TR, Ellis-Evans JC, Clarke A (1993) Measurements of seasonal rates and annual budgets of organic carbon fluxes in an Antarctic coastal environment at Signy Island, South Orkney Islands, suggest a broad balance between production and decomposition. Appl Environ Microbiol 59:3989-3995

Oudot C, Gerard R, Morin P, Gningue I (1988) Precise shipboard determination of total dissolved oxygen (Winkler procedure) for productivity studies with a commercial system. Limnol Oceanogr 33:146-150

Parsons TR, Maita Y, Lalli CM (1984) A manual of chemical and biological methods for seawater analysis. Pergamon Press, Oxford

Pedrós-Alió C, Mas J (1993) Bacterial sinking losses. In: Kemp PF, Sherr BF, Sherr EB, Cole JJ (eds) Handbook of methods in aquatic microbial ecology. Lewis Publishers, Boca Raton, p 677-684

Peters E, Thomas DN (1996) Prolonged darkness and diatoms mortality. I. Marine Antarctic species. J Exp Mar Biol Ecol 207:25-41

Sakshaug E (1993) The relationship between phytoplankton growth rate and production with emphasis on respiration and excretion. ICES Mar Sci Symp 197:63-68

Sommer U (1989) Maximal growth rates of Antarctic phytoplankton: only a weak dependence on cell size. Limnol Oceanogr 34:1109-1112

Strathmann R (1967) Estimating the organic carbon content of phytoplankton from cell volume or plasma volume. Limnol Oceanogr 12:411-418

Submitted: November 22, 1999; Accepted: March 21, 2000 Proofs received from author(s): October 9, 2000 